\title{
Model City Branding Melalui Revitalisasi Sungai Cikapundung
}

\author{
${ }^{1}$ Iis Saidah, ${ }^{2}$ Agustin Rozalena \\ Politeknik Piksi Ganesha, J1. Gatot Subroto No.301, Batununggal, Kota Bandung, Jawa Barat \\ E-mail: 'iissaidah88@gmail.com,2alen.rozalena@gmail.com
}

\begin{abstract}
Abstrak: Penelitian ini bertujuan untuk mengontruksi model city branding melalui revitalisasi Sungai Cikapundung. Model city branding merupakan penelitian bersifat kualitatif studi kasus dengan paradigma konstruksi. Teknik pengumpulan data dilakukan melalui Focus Group Discussinon (FGD), observasi nonpartisipasi, wawancara mendalam dan literatur serta teknik analisis data dengan Model Interaktif. Hasil penelitian menyatakan 1). Proses branding Kota Bandung terbangun melalui proses revitalisasi Sungai Cikapundung, sehingga membentuk wisata buatan Kota Bandung yang khas 2) Strategi branding dalam mempromosikan sungai kota dilakukan dengan mengomunikasikan keunggulan sungai Cikapundung sebagai objek wisata buatan melalui berbagai event, membentuk persepsi masyarakat tentang citra sungai, meningkatkan daya tarik Sungai Cikapundung, sehingga meningkatkan kunjungan wisata 3). Model city branding melalui revitalisasi Sungai Cikapundung memenuhi aspek pada Model Octagone dan menambahkan aspek penting lainnya, yaitu preservation the environments, sehingga terbentuk model baru, yaitu Model Nanogone. Kesimpulan penelitian ini 1). Revitalisasi Sungai Cikapundung menciptakan branding Kota Bandung 2). Strategi branding meningkatkan kunjungan wisata ke Kota Bandung 3). Preservation the environments sebagai pembentuk model Nanogone memberikan kesadaran tentang lingkungan kepada masyarakat.
\end{abstract}

Katakunci: city branding, revitalisasi sungai cikapundung, model hexagone, model octagone, model nanogone.

Abstract: This study aims to construct the city branding model through the revitalization of the Cikapundung River. It is a qualitative case study research formulated by contruction paradigm. Data collection techniques were carried out through Focus Group Discussions (FGD), nonparticipant observation, in-depth interviews and literature as well as data analysis techniques with the Interactive Model. The results are 1). The process of Bandung city branding established through Cikapundung revitalization river effects, which boosted the specific artificial tourism in Bandung city 2). The branding stategy to promote the river are achieved by publicizing the artificial tourism superiority of Cikapundung river as a tourism spot through some events, creating the same perception about the river's image among people and increasing the attractiveness of Cikapundung river. 3). The city branding design has an Octagone design aspects and adding other important aspect that is preservation of the environment that formed Nanogone model. The conclusion are 1). The revitalization of cikapundung river create branding of Bandung city 2). The branding stategy increase tourist visit to Bandung city 3). Preservation the environments as forming the Nanogone design raise the awareness about environments.

Keywords: city branding, cikapundung river's revitalization, hexagone model, octagone model nanogone model.

DOI: https://doi.org/10.29313/mediator.v12i2.5026 


\section{PENDAHULUAN}

Kota Bandung merupakan kota metropolitan yang citra kotanya mulai menjadi ikon kota kreatif dan seni di Indonesia. Strategi pariwisata muncul dalam pesan dan makna tempat, wilayah, dan fasilitas strategis. Peran Badan Promosi Pariwisata Bandung (BP2KB) dalam mengelola komunikasi merek kota mulai dirasakan berdampak meningkatnya wisatawan lokal maupun mancanegara ke Kota Bandung. Pola komunikasi merek yang dibangun antara pemerintah kota dengan masyarakat adalah dengan terwujudnya layanan objek wisata baru bagi wisatawan, seperti sentra kreativitas, taman kota tematik, maupun fasilitas "Bandung tour on bus" alias bandros. Pemerintah Kota Bandung memperkuat slogan kota dengan nama "Bandung Bermartabat". Pemberian slogan tersebut telah disesuaikan dengan Rencana Pembangunan Jangka Panjang (RPJP) dan telah disepakati hingga 2025.

Pengenalan slogan secara perlahan membangun kembali citra Kota Bandung yang dahulu dikenal masyarakat sebagai kota kembang, kota ramah dan bersahaja, serta kota multi talenta. Semakin banyaknya pusat wisata kota, maka peluang untuk menjadikan sumber pendapatan baru bagi pemerintah kota, sehingga kesan kota semakin resik dengan tambahan infratruktur yang ramah lingkungan semakin terbuka pula. Kini,Pemkot mulai berkonsentrasi melirik tempat-tempat wisata potensial baru, seperti halnya dengan potensi aliran Sungai Cikapundungyang mengaliri Kota Bandung dapat menjadi alternatif objek pariwisata lingkungan.

Berkembangnya pariwisata lingkungan tidak terlepas dari keinginan pemerintah kota untuk mengatasi permasalahan sungai dikarenakan banyaknya warga yang masih bermukim di bantaran sungai.Sungai yang mengalir di sisi rumah tak urung menjadi tempat pembuangan limbah kotoran. Oleh sebab itu, gagasan penataan sungai yang digaungkan lebih dari sepuluh tahun ini lebih bersifat kembali ke alam, namun tetap dapat aktif digunakan masyarakat untuk berinteraksi. Adapun potensi untuk direvitalisasi adalah kualitas air, kualitas hutan kota di sekitar sungai, hingga kualitas ruang, tanpa meninggalkan sifat sosial aktif untuk berinteraksi masyarakat, termasuk sebagai aset penopang pariwisata kota.

Promosi dengan berbagai dukungan komponen komunikasi pemasaran yang tepat dapat membantu kota menawarkan kepada pengunjung melalui manfaat apa yang diterima sehingga merasakan kepuasan setelah meninggalkan kota. Berkaitan dengan fungsi daya tarik kota untuk masyarakat dan wisatawan, maka pemerintah mulai melirik potensi sungai kota ini untuk dijadikan ikon melalui city branding. Menurut Keith Dinnie, ketertarikan pada city branding dapat dilihat sebagai bagian dari pengakuan yang lebih luas tempat-tempat dari semua jenis dapat memperoleh manfaat dari penerapan strategi koheren dengan mengelola sumber daya, reputasi, dan citra mereka (Dinnie, 2010).

Pada praktiknya, Kota Bandung bukanlah satu-satunya kota yang sedang bergairah menambah wisata buatannya dengan menyandingkan dengan wisata berterma lingkungan. Tentu hal ini menjadi penguat keberadaan kota dan memberi alternatif wisatawan untuk menentukan pilihan tujuan wisata. Meski demikian, seiring dengan strategi yang dibangun, maka promosi kota tetap harus dilakukan. Dalam pelaksanaannya, para pemangku kepentingan masih membatasi promosi objek wisata kota buatan ini hanya dibebankan kepada Dinas Pariwisata dan Kebudayaan Kota Bandung saja. Demikian halnya dengan dukungan media yang dimiliki oleh Disparbud, namun kendala penerapan 
komunikasi pemasaran masih sangat mengandalkan peran serta dan back up dari dinas lainnya. Dukungan masyarakat juga muncul dikarenakan peran word of mouth yang berlangsung massif, pembuktian ke lapangan atau menyenaga datang ke lokasi merupakan kesan bahwa branding kota memerlukan strategi pemilihan pesan promosi. Caldwell dan Freire (2010) berpendapat bahwa sebuah tempat sama halnya dengan produk apa pun,setiap fungsi kota juga mencakup ciri-ciri simbolik yang menunjukkan bahwa kota tersebut memiliki makna simbolik layaknya produk pada umumnya. Tidak hanya itu, selama beberapa dekade sekarang, kota-kota di seluruh dunia telah menerapkan teknik pemasaran dan semakin mengadopsi filosofi pemasaran untuk memenuhi tujuan operasional dan strategis mereka (Kavaratzis, 2007).

Pada penelitian merek kota yang dilakukan oleh Mihalis Kavaratzis (2007), menyatakan bahwa selama beberapa dekade sekarang, kota-kota di seluruh dunia telah menerapkan teknik pemasaran dan semakin mengadopsi filosofi pemasaran untuk memenuhi tujuan operasional dan strategis mereka. Hal ini senada dengan beberapa penelitian yang sudah dilakukan pada kota-kota di Indonesia, seperti kota Purwakarta dengan city branding-nya "Purwakarta Istimewa" terbukti memiliki pengaruh yang signifikan terhadap keputusan wisatawan untuk berkunjung ke Purwakarta. Penelitian yang dilakukan oleh Indriani, Jesi dan Chandra Kuswoyo (2017) membuktikan bahwa city branding yang dibangun oleh pemerintah Kota Purwakarta berhasil menarik wisatawan untuk berkunjung.

Demikian pula dengan kota Malang yang memiliki city branding "Shining Batu". Penelitian yang dilakukanWandari, Lita Ayu., Srikandi Kumadji dan Andriani Kusumawati. (2014), menyatakan secara signifkan bahwa city branding
Kota Malang berpengaruh terhadap keputusan berkunjung ke Kota Malang, sehingga berdampak positif bagi citra kota. Selain itu, penelitian Lily Purwianti dan Yulianty Ratna Dwi Lukito (2014), menyatakan dalam simpulan hasil penelitiannya menunjukkan bahwa faktor-faktor yang mempengaruhi brand city Kota Batam sebagai tempat tinggal bagi penduduk Kota Batam adalah faktor business opportunity, social bonding dan networking.

Adapun untuk penelitian yang berhubungan dengan Kota Bandung sendiri, Maylanny Christin dan Siti Faridani Fauzan (2015), menyatakan bahwa city branding Kota Bandung melalui city tour on bus merupakan salah satu komponen untuk memenuhi salah satu indeks agar Bandung dapat menjadi kota wisata dunia. Oleh karena itu, keberadaan Bandung Tour On Bus atau dikenal sebagai Bandros merupakan kerjasama masyarakat Bandung dengan Pemerintah Kota Bandung, terutama untuk penamaan armada dan desain bus. Dalam mempromosikan Bus Bandros, Pemerintah Kota Bandung menggunakan media sosial Twitter untuk berbagi informasi kepada seluruh lapisan masyarakat. Dalam Twitter tersebut terdapat informasi mengenai prosedur jika ingin naik bus Bandros dengan cara reservasi, jadwal atau rute, biaya, dan lain-lain. Hal tersebut dipilih karena banyak orang yang menggunakan, juga pihak pengelola lebih memahami media tersebut dibandingkan yang lainnya.

Adapun penelitian yang menyoroti tentang revitalisasi sungai, salah satunya dilakukan oleh Damayanti, dkk, pada Kali Pepe Hilir, Surakarta, menyatakan bahwa revitalisasi sungai yang dilakukan oleh DPU Kota Surakarta merupakan upayauntuk mengembalikan fungsi sebagai saluran drainase primer dan termasuk dalam bagian sistem drainase Kota Surakarta. Penelitian ini 
menunjukkan bahwa Kota Surakarta dapat mengatasi dampak negatif citra kota.

Selain penelitian sejenis, hasil penelitian penulis berkaitan dengan komunikasi merek kota (city branding) yang dilakukan penulis pada tahun 2014 hingga 2017 menujukkan bahwa berbagai sudut kajian dan aset kota dapat menjadi modal branding kota untuk promosi pariwisata. Penulis berkeyaninan bahwa Pemerintah Kota Bandung melalui Badan Promosi Pariwisata Bandung (BP2KB) melakukan strategi manajemen untuk mengelola komunikasi merek kota dengan berkonsentrasi pada tiga pilar konsep komunikasi pemasaran terpadu yang diemukakan, yaitu mengidentifikasi target audiens dan membangun pemasaran pariwisata atau program komunikasi (berfokus pada khalayak). Kedua, merencanakan dan melibatkan saluran komunikasi (berfokus pada saluran/media) dan ketiga, mengukur hasil program, mengevaluasi program komunikasi pemasaran melalui nilai pendapatan kota.

\section{Komunikasi merek kota}

Merek dipahami sebagai kumpulan identitas, citra, dan aspirasi. Identitas menunjukkan alasan mengapa sebuah kota harus memiliki slogan atau merek yang sangat berbeda dari kota-kota lain dan memiliki ciri khas. Citra merek diidentifikasi dengan merek apa yang diwakili oleh kota. Brand atau merek diartikan juga sebagai sesuatu yang dapat menjalankan keseluruhan dari proses komunikasi campuran dari atribut, berbentuk sebuah logo atau simbol yang mencerminkan sebuah janji atau proses emosional antara konsumen dan perusahaan dan menciptakan pengaruh yang bernilai untuk stakeholder dan konsumen (Mathieson \& Wall, 2005). Dalam konteks komunikasi pemasaran, perusahaan maupun para pengusaha berusaha menginformasikan, membujuk, dan mengingatkan konsumen secara langsung dan tidak langsung mengenai produk yang dimilikinya (Rozalena, 2017).

Hal ini pun ditegaskan oleh Kotler dan Keller yang menyatajan bahwa di dalam kesadaran merek terdapat kemampuan untuk mengidentifikasi kategori. Calon pengunjung kota dapat mengenali dan mengingat kota melalui slogan atau merek kota secara mendetail. Model proses komunikasi menekankan faktor-faktor kunci dalam komunikasi yang efektif (Kotler \& Keller, 2008). Komunikasi merek mensyaratkan kredibilitas sumber pesan dan dukungan setia pada visi Kota Bandung.

$\begin{array}{ccr}\begin{array}{c}\text { Beberapa } \\ \text { menunjukkan }\end{array} & \begin{array}{c}\text { kota di } \\ \text { konsep }\end{array} & \begin{array}{r}\text { Indonesia } \\ \text { branding }\end{array}\end{array}$
berdasarkan penamaan kota yang unik dan menarik. Hal ini berarti bahwa city branding yang dibangun oleh pemerintah berhasil menarik wisatawan untuk berkunjung (Indriani \& Kuswoyo, 2017). Bahkan, secara signifkan city branding berpengaruh terhadap keputusan berkunjung ke suatu kota, sehingga berdampak positif bagi citra kota (Wandari, Kumadji, \& Kusumawati, 2014).

Faktor-faktor business opportunity, social branding dan networking juga mempengaruhi brand (Purwianti dan Lukito, 2014). Hal ini menunjukkan bahwa kerjasama masyarakat kota dengan pemerintah kota dapat memperkuat posisi tawar saat dipromosikan kepada masyarakat.

\section{Pemilihan Media Branding}

Branding kota juga memerlukan media, terutama untuk mempromosikan objek wisata lingkungan. Pemerintah kota menggunakan media sosial twitter untuk berbagi informasi kepada seluruh lapisan masyarakat. Dalam twitter tersebut terdapat informasi mengenai 
prosedur jika ingin berwisata dengan cara reservasi, jadwal atau rute, biaya, dan lain-lain. Berdasarkan sekian banyak sosial media seperti twitter, whatsapp, dan instagram. Hal tersebut dipilih karena banyak orang yang menggunakan, juga pihak pengelola lebih memahami media tersebut dibandingkan yang lainnya, seperti yang diterapkan pada wisata Bandros (Bandung Tour On Bus) (Maylanny \& Faridani, 2015).

Berkaitan dengan komunikasi merek kota (city branding) yang dilakukan penulis pada tahun 2014 hingga 2017 menujukkan bahwa berbagai sudut kajian dan aset kota dapat menjadi modal branding kota untuk promosi pariwisata. Penulis berkeyaninan bahwa Pemerintah Kota Bandung melalui Badan Promosi Pariwisata Bandung (BP2KB) melakukan strategi manajemen untuk mengelola komunikasi merek kota dengan berkonsentrasi pada tiga pilar konsep komunikasi pemasaran terpaduyaitu mengidentifikasi target audiens dan membangun pemasaran pariwisata atau program komunikasi (berfokus pada khalayak). Kedua, merencanakan dan melibatkan saluran komunikasi (berfokus pada saluran/media) dan ketiga, mengukur hasil program, mengevaluasi program komunikasi pemasaran melalui nilai pendapatan kota.

\section{Revitalisasi Sungai}

Dalam kamus Bahasa Indonesia, revitalisasi adalah proses, cara, perbuatan menghidupkan atau menggiatkan kembali. Revitalisasijuga dikatakan sebagai suatu proses atau cara dan perbuatan untuk menghidupkan kembali suatu hal yang sebelumnya terberdaya sehingga revitalisasi berarti menjadikan sesuatu atau perbuatan untuk menjadi vital, sedangkan kata vital mempunyai arti sangat penting atau sangat diperlukan sekali untuk kehidupan dan sebagainya.

Revitalisasi sungai sebenarnya merupakan bagian dari city branding pemerintah kota yang bekerjasama dengan warga untuk menciptakan kota sesuai dengan slogan yang dipromosikan, yaitu Bandung Bermartabat. Khusus dalam kaitannya dengan strategi pemasaran pariwisata, maka pemerintah dapat memperkenalkan atribut merek ini kelak dalam bentuk pesan yang membudaya budaya lokal, mudah dipahami dan mudah dilakukan melalui aliran Sungai Cikapundung.

Hal penting dari revitalisasi sungai merupakan upaya untuk mengembalikan fungsi sebagai saluran drainase primer dan termasuk dalam bagian sistem drainase kota (Damayanti, Nurhadi, \& Andini, 2015).

\section{METODE}

Penelitian ini menggunakan pendekatan kualitatif melalui paradigma konstruktivisme serta analisis studi kasus. Pada penelitian yang bersifat kualitatif pengambilan data berdasarkan narasumber atau informan, sehingga teknik pengambilan sampel yang digunakan adalah purposive sampling.

Objek penelitian ini adalah city branding yang merupakan penamaan merek kota yang khas dan menarik. Subjek penelitian ini adalah informan individu yang terlibat pada proses branding kota yang terdiri dari unsur pemerintah Kota Bandung terkait serta individu dari kelompok pemangku kepentingan kota dan masyarakat sekitar Sungai Cikapundung, Bandung.

Teknik pengumpulan data primer dilakukan dengan dengan tiga cara yaitu, 1) Focus Group Discussion (FGD) bersama komunitas yang tergabung dalam Kelompok kerja (Pokja) Cikapundung; 2) observasi nonpartisipasi di kawasan sungai Cikapundung yang direvitalasi, di antaranya Babakan Siliwangi dengan wisata Teras Cikapundung, Kecamatan Regol dengan area Alun-alun Regol dan 
kawasan Asia Afrika dengan objek wisata Cikapundung Riverspot; 3) wawancara mendalam berhubungan dengan informasi dan pelaksanaan revitalisasi sungai serta perencaaan program pariwisata yang dilakukan kepada Bagian Program Pariwisata, Dinas Pariwisata dan Kebudyaan, pejabat terkait pelaksana revitalisasi Alun-alun Regol, Kepala Seksi Pembangunan dan Pengendalian Sumber Daya Air Dinas Pekerjaan Umum, Balai Besar Wilayah Sungai (BBWS) Citarum dalam pembangunan Teras Cikapundung dan Cikapundung Riverspot, Kepala Staf Perencana Tata Ruang Dinas Tata Ruang Kota Bandung, Kepala Seksi Pencegahan Pencemaran Lingkungan Dinas Lingkungan Hidup Kota Bandung. Adapun wawancara terstruktur dilakukan kepada wisatawan dan masyarakat pada delapan kecamatan di Kota Bandung yang bermukim di sekitar Sungai Cikapundung. Penelitian ini juga didukung oleh data sekunder menggunakan studi literatur berupa dokumen/arsip yang berasal dari dinasdinas terkait, baik cetak maupun konten dalam website.

Adapun teknik analisis data menggunakan Teknik Interaktif, yaitu setelah dataterkumpul, penelitimelakukan kategorisasi dan mereduksi data, sehingga membentuk data yang dapat dianalisis atau diinterpretasikan. Selanjutnya, peneliti mengkontruksi model data serta mendefinisikan model sebagai kumpulan informasi terstruktur yang memungkinkan deskripsi kesimpulan dan tindakan yang diambil. Terakhir peneliti memverifikasi kesimpulan.

\section{HASIL DAN PEMBAHASAN \\ Proses Branding Kota Bandung}

City branding dapat membentuk identitas sebuah kota yang berguna untuk mengomunikasikan atau memasarkan segala aktifitas kegiatan, tempat wisata, makanan budaya dan aspek lainnya.
Secara umum Kota Bandung tidak memiliki potensi wisata alam, melainkan hanya wisata buatan. Wisata buatan yang berhasil diciptakan salah satunya dengan penataan bataran Sungai Cikapundung yang kemudian menjadi objek wisata yang banyak dimintai sekaligus menjadi brand dari Kota Bandung itu sendiri.

Branding yang terbentuk melalui Sungai Cikapundung saat ini merupakan hasildari proses revitalisasi Sungai Cikapundung yang selama ini memilliki citra negatif. Melalui Balai Besar Wilayah Sungai (BBWS) Citarum, dinyatakan oleh A. Yayat Yuliana selaku Pejabat Pembuat Komitmen Operasi dan Pemeliharaan I SDA Citarum, bahwa revitalisasai Sungai Cikapundung pada dasarnya dilakukan dengan tujuan untuk menyelamatkan aset negara, mengembalikan fungsi bantaran dan sempadan sungai. Branding Kota Bandung melalui revitalisasi Sungai Cikapundung, sebenarnya bukan tujuan awal dari revitalisasi itu dilakukan. Revitalisasai yang terkonsep dengan baik dan kemudian menjadi ikon tersendiri itulah yang kemudian dengan sendirinya wisata Sungai Cikapundung menjadi Branding (Yuliana, 2019)

Wisata buatan Sungai Cikapundung memiliki potensi yang besar tidak hanya dalam bidang pariwisata, tapi juga dalam bidang pendidikan, keagamaan, lingkungan hidup, pertanian, perikanan dan kehutanan. Potensi besar dari revitalisasi Sungai Cikapundung berhasil diciptakan karena adanya sebuah kreatifitas. Hal ini senada dengan tercatatnya Kota Bandung sebagai $\mathrm{CCN}$ (Creative Cities Network) atau kota kreatif dunia. Staf Bidang Program Data Informasi Dinas Pariwisata dan Kebudayaan Kota Bandung menyatakan bahwa Kota Bandung dalam tercatat sebagai CCN (Creative Cities Network) atau kota kreatif dunia dan yang kedua terkait dengan stunning Bandung (Nugraha, 2019). Berdasarkan brand 
dan potensi yang tercipta dari Sungai Cikapundung ini menunjukan bahwa Kota Bandung memiliki identitas berupa nama, logo, citra dan symbol atau ikon kota yang melekat.

\section{Strategi Branding dalam Mempromosikan Sungai Kota Sebagai Objek Wisata Baru}

City brandingdapat berkaitan dengan tata rencana kota yang dapat dijadikan sebuah strategi dari suatu kota untuk mempromosikan kota itu sendiri. Strategi branding merupakan sebuah manajemen yang bertujuan untuk membentuk sebuah brand dalam kaitannya dengan sikap dan perilaku target sasaran. Sungai kota yang direvitalisasi salah satunya Sungai Cikapundung disesuaikan dengan karakterisrtik kota dan masyarakat saat ini. Kota Bandung yang tidak memiliki wisata alam, dengan kreatifitas dibuatlah wisata buatan dari proses revitalisasi ini. Dalam hal karakteristik masyarakat saat ini yang cenderung menyukai kegiatan outdoor dan mengambil gambar untuk diunggah di sosial medianya. Berdasarkan hal tersebut, wisata buatan melalui revitalisasi Sungai Cikapundung sangatlah tepat dan terbukti menarik wisatawan lokal, nasional bahkan internasional untuk berkunjung walau tujuannya tidak sekadar wisata tetapi juga berkaitan dengan pendidikan dan lainnya. Selain itu, otomatis sesuai dengan program wali kota Bandung 2014-2018, revitalisasi ini ditujukan dalam meningkatkan indeks kebahagiaan warga.

Kunjungan wisatawan Sungai Cikapundung, tidak terlepas dari peran berbagai pihak terutama Dinas Kebudayaan dan Pariwisata Kota Bandung. Badan Promosi Pariwisata Bandung (BP2KB) menyusun strategi manajemen untuk mengelola komunikasi untuk melakukan promosi event atau memperkenalkan tempat wisata termasuk sungai Kota Cikapundung. Strategi komunikasi yang dilakukan BP2KB dilakukan secara rutin baik secara online atau offline. Promosi offline, yaitu pada acara talk show di radio, presentasi pada kegiatan dinas atau event lainnya seperti pada saat pembukaan rute penerbangann Bandung-Singapura, Singapura-Bandung untuk maskapai Garuda Indonesia Airline. Promosi online, yaitu melaui Twiter, Facebook, Instagram dan website. Angga Nugraha memaparkan program pariwisata yang dilakukan secara rutin melalu event dilakukan Dinas Pariwisata dan Kebudayaan juga didukung oleh media internet. Kepala Disparbud setiap presentasi selalu mambahas objek wisata potensi, meski tidak secara spesifik, namun semua objek wisata yang dimiliki Kota Bandung termasuk aneka taman yang menjadi wisata kota buatan (Nugraha, 2019).

Selain itu, promosi yang dilakukan melalui twiter dengan link Dinas Kebudayaan dan Pariwista Kota Bandung @Disparbud_bdg ini memposting berbagai event baik sebelum, selama atau setelah event tersebut dilakukan. Disparbud Kota Bandung mulai berpromosi melalui twiter pada bulan september 2013 dengan follwers sampai saat ini sebanyak 14700 followers. Facebook, yaitu Dinas Kebudayaan dan Pariwisata Kota Bandung menampilkan alamat Disparbud dan identitas lainnya seperti nama instragram, waktu operasional dan lainnya. Informasinya lebih lengkap dari twiter dan instagram, yaitu dengan menampilkan tempat-tempat wisata juga tentang sejarah atau asal usul sejarah seni,budaya dan tempat yang ada di Kota Bandung. Publikasi di Facebook dan Instrgram bersifat rutin perevent, bahkan di website lebih lengkap karena menampilkan kalender program promosi (Nugraha, 2019).

Seperti dikethaui, media social Instagram Disparbud.bdg sampai saat 
ini telahdiikuti 12900 follower, adapun informasinya sama dengan yang terdapat di Facebook. Demikian pula website Disparbud menampilkan informasi paling lengkap dibandingkan dengan media sosial lainnya yang digunakan, dikarenakan di dalam link Disparbud, yaitu Bandung.go.id ini memaparkan kalender program tahunan Disparbud Kota Bandung. Informasi yang berada dalam website juga memuat berbagaievent seni budaya dan pariwisata Kota Bandung, tempat populer pariwisata Kota Bandung dan jenis seni budaya Sunda yang dimiliki Kota Bandung seperti pencak silat, kendang dan lainnya.

Strategi branding secara spesifik dimulai dari dilakukannya program dinas di Kota Bandung melalui aspek Bandung kota kreatif yang atraktif, aksesibilitas, dan amenitas(3A), yaitu lokasi strategis wisata, peduli lingkungan dan mudah dikenali.

\section{Penguatan unsur $3 \mathrm{~A}$}

Unsur 3A ini mencakup kota dengan atraksi, aksesibilitas dan amenitas yang dimiliki oleh Kota Bandung. Hal ini secara tidak langsung dengan unsur 3A, terbentuk brand positioning dilakukan dengan cara strategi promosi dengan cara mengomunikasi berbagai keunggulan dari Sungai Cikapundung. Wisata buatan sungai kota hasil revitalisasi ini tidak hanya untuk kegiatan wisata secara umum, tetapi sebagai sarana pendidikan, olahraga, keagamaan dan lainnya. Dalam hal sarana pendidikan, sungai hasil revitalisasi sering menjadi target kunjungan murid sekolah mulai tingkat TK sampai dengan pergurusan tinggi serta sering dijadikan objek penelitian. Dalam kegiatan olahraga dan keagamaan, yaitu tempat ini secara rutin dilakukan kegiatan tersebut. Setiap hari Jumat di Teras Cikapundung terdapat kegiatan pengajian begitu juga setiap hari minggu aerobik dilakukan secara rutin diAlun-Alun Regol. Oleh karena itu, Kota Bandung menjadi bagian dari 10 destinasi pariwisata utama Indonesia, dalam upaya menyelaraskan sub-brand (branding destinasi) dengan master-brand Wonderful Indonesia oleh Kementrian Pariwisata tahun 2017.

2. Menciptakan tageline Stunning Bandung: where the wonders of West Java begin.

Tagline Stunning Bandung: where the wonders of West Java begindisertai dengan logo bunga dan kujang berarti simbol keindahan, orisinalitas dan otentisitas Jawa Barat. Slogan dalam bahasa Inggris untuk menjelaskan Bandung yang kaya sejarah, budaya, seni, dan kuliner, serta keindahan alamnya.

Tagline ini otomatis menumbuhkan identitas pada Kota Bandung, sehingga membentuk persepsi masyarakat mengenai wisata yang mempesona dan menarik bagi yang datang. Demikian pula pada Sungai Cikapundung yang sebelum dan setelah revitalisasi dilakukan, daya tarik wisata mencari alternatif wisata berorientasi lingkungan alam, namun tetap berada di kota. Sebagaimana diketahui kawasan Sungai Cikapundung awalnya dikenal sebagai wilayah yang kumuh, seram bahkan menjadi tempat pembungan sampah, namun berkat kerja keras berbagai pihak yang terkait, bantaran dan sempadan sungai mulai beralih menjadi taman kota baru, yaitu Teras Cikapundung, Cikapundung River Spot juga Alun-Alun Regol. Bantaran dan sempadan sungai yang disalahgunakan telah bermetamorposis menjadi wisata buatan yang banyak diminati tidak hanya oleh kaula muda, dewasa tetapi anak-anak juga. Dengan demikian, telah terbentuk citra atau brand dari Sungai Cikapundung tersebut menjadi wilayah yang ramah, asik dan menyenangkan.

3. Mendukung Program Ruang Ramah Lingkungan dan Menyenangkan

Keberadaan taman kota yang didalamnya termasuk Teras Cikapundung, Cikapundung River Spot dan Alun- 
Alun Regol adalah bentuk upaya dari pemerintah dalam hal meningkatkan kenyamanan warga serta dukungan untuk peduli lingkungan. Kerjasama pemerintah mulai dari Balai Besar Wilayah Sungai (BBWS), Dinas Pekerjaan Umum, Dinas Kebudayaan dan Pariwisata, Tata Ruang dan Lingkungan Hidup serta dengan komunitas pegiat dan peduli Sungai Cikapundung. Seperti diketahui, Sungai Cikapundung adalah bagian dari aliran Sungai Citarum yang sudah menjadi issue national dan internasional. Oleh karena itu, dalam upaya meningkatkan daya tarik wisata sungai kota ini dapat dilakukan dengan mengelola, membenahi, termasuk mengomunikasikan visi kota. Selanjutkan sharing pengalaman mengenai wisata Sungai Cikapundung ini akan dilakukan oleh para pengujung yang merasa puas berwisata atau berkunjung ke sungai kota tersebut. Daya tarik diciptakan dengan dilaksanakan event di tempat tersebut juga dengan cara pengelola terus membenahi dan memelihara wilayah tersebut walaupun belum dilakukan secara maksimal. Kenyamanan yang dirasakan penggunjung biasanya secara tidak sadar akan mereka mempromosikan kepada tetangga, teman kerabat, bahkan mereka publikasikan dalam sosial media yang mereka miliki.

4. Promosi wisata kota

Promosi destinasi Sungai Cikapundung dilakukan dengan cara mengomunikasikan bersamaan dengan destinasi wisata kota Bandung lainnya. Pilihan untuk berwisata lingkungan dengan keberadaan sungai kota yang telah direvitalisasi baik secara internal ataupun eksternal dilakukan secara langsungmelalui personal sellingdan event. Tempat wisata Sungai Cikapundung sering kali dijadikan sebagai tempat pertunjukan budaya atau event lainnya, dengan demikian berarti secara tidak langsung mempromosikan wisata sungai tersebut. Strategi ini pun dapat mengarahkan seseorang atau sekelompok orang yang kurang tertarik dengan wisata buatan. Dengan adanya pertunjukan yang mereka minati mereka datang ke tempat wisata buatan tersebut yang notabene wisata Sungai Cikapundung dan merekapun sedikitnya akan mengetahui, bahkan menikmati dan mengomunikasikan kepada yang lainnya.

\section{Model City branding Kota Bandang melalui Revitalisasi Sungai Cikapundung}

Penerapan city branding melalui revitalisasi Sungai Cikapundung dilakukan dengan melaksanakan strategi city branding. Implementasi strategi city branding ini memiliki tiga sasaran strategis, yaitu identitas, marketing dan citra.

1. Identitas Kota

Kota Bandung sebagai kota yang memiliki julukan Paris van Java dan Organisasi Pendidikan, Keilmuan dan Kebudayaan Perserikatan Bangsa-Bangsa (United nations Educational, Scientific and Culture organization - UNESCO mengumumkan Kota Bandung tercatat sebagai salah satu dalam jaringan kota kreatif, UNESCO mengukuhkan identitas Kota Bandung itu sendiri. Identitas kreatifitas Kota Bandung selain dalam bentuk desain juga melalui pembanguan infrastuktur, termasuk salah satunya dalam reviatalisasi Sungai Cikapundung.

Sungai Cikapundung yang telah direvitalisasi meliputi tiga titik yaitu yang dikenal dengan Teras Cikapundung, Cikapundung River Spot dan Alun-Alun Regol. Revitalisasi sungai tersebut telah menjadi salah satu wisata buatan yang kini banyak diminati untuk dikunjungi oleh wisatawan. Hal itu menunjukan bahwa Sungai Cikapundung telah menjadi identitas kota, karena identitas kota dapat diketahui dari banyaknya kunjungan wisata ke tempat tersebut. Seiring dengan terbentuknya identitas 
Sungai Cikapundung, maka terciptalah wisata sungai kota di Bandung, yaituTeras Cikapundung.

2. Pemasaran

Kota Bandung yang sudah dikenal luas dengan berbagai identitas juga menyertakan slogan. Slogan Kota Bandung adalah "Bandung The Inspiring City"denganlogoyangmenyerupaikepala burung sebagai aktivitas pemasaran Kota Bandung. Potensi besar yang dimiliki Kota Bandung harus seiring dengan kegiatan marketing yang dilakukan. Aktivitas marketing akan efektif apabila ditunjang dengan komunikasi pemasaran yang tepat.

Dalam upaya mendukung komunikasi pemasaran wisata Sungai Cikapundung yang relatif masih baru, Badan Promosi Pariwisata Bandung (BP2KB) menyusun strategi komunikasi untuk mengenalkan dan meningkatkan kunjungan wisata sungai ini, yaitu secara online, offline dan melalui event. Komunikasi pemasaran secara offline danonline dilakukan secara langsung. Komunikasi pemasaran secara online dilakukan lebih gencar dan detail dengan penyebaran informasi melalui media sosial dan memberi akses penjelajahan secara online untuk lokasi-lokasi yang tersebar. Komunikasi pemasaran melalui event dengan cara wisata sungai dijadikan tempat event itu dilakukan, dengan kata lain komunikasi pemasaran dilakukan secara tidak langsung.

\section{Citra}

Citra Kota Bandung terbetuk melalui city branding dapat dilihat dari penerapan model Hexagone menurut Simon Anholt (Papp-Vary, 2011) terdapat enam aspek dalam pengukuran efektivitas city branding dan dua komponen hasil penelitian Agustin Rozalena (Rozalena, 2019) serta satu komponen dari hasil penelitian yang dilakukan sebagai berikut. a. Presence. Tahap ini, wisata sungai kota termasuk dalam wisata buatan
Kota Bandung yang memiliki keunggulan, ciri khas suatu kota dengan adanya persepsi Kota Bandung yang nyaman berkeliling kota dan jalan-jalan. Wisata Sungai Cikapundung terciptakarenaadanya revitalisasi untuk penataan wilayah kumuh dan menyelamatkan aset negara, namun juga didalamnya termasuk aspek wisata, pendidikan, lingkungan, keagamaan, pertainan, peternakan dan kehutanan. Konsep wisata buatan yang multi aspek dan tujuan ini tetap mengutamakan keindahan dankenyamanan saat berada dilokasi.

b. Place. Lokasi wisataSungai Cikapundung berada pada tiga tempat yang dikenal dengan sebutan Cikapundung River Spot, Teras Cikapundung dan AlumAlun Regol. Ketiga tempat wisata sungai ini sangat strategis yang berada ditengah kota sehingga memberikan akses kemudahan untuk menjangkau tempat tersebut baik menggunakan transportasi umum ataupun pribadi.

c. Potensial.Wisata buatan Sungai Cikapundung memiliki peluang ekonomi dan pendidikan. Wisatawan akan melakukan transaksi mulai dari kedatangan, menginap di hotel, menikmati sajian kuliner di restoran, dan berbelanja oleh-oleh. Kontribusi pendapatan pariwisata juga bisa dilihat dari meningkatnya jumlah wisatawan sekitar 10 hingga 15 persen setiap tahun. Elemen ini merupakan salah satu langkah dalam menunjukkan keunggulan dibandingkan nilai dasar IMC, yang bertujuan memberi kontribusi nyata pada hasil bisnis.

d. Pulse. Kota Bandungsarat dengan ragam gaya hidup yang kentara. Satu sisi, dengan wisata budaya dan religious menguatkan latar belakang 
adat dan Budaya Sunda serta sikap religi yang masih sangat tinggi, pada sisi lain, modernitas pada produk dan hegemoni barat tidak dapat terabaikan dengan adanya wisata rekreasi hiburan di mal, seperti Trans Studio, Transmart, Yogya dan Bandung Indah Plaza dan sebagainya. Berbagai taman yang memiliki konsep berbeda dibangun dalam upaya mengakomodasi pusat kegiatan masyarakat.

e. People. Keramahtamahan merupakan citra yang dibangun sejak dahulu adalah satu alasan meningkatkan indeks kebahagiaan bagi warga Bandung sendiri, melainkan juga bagi wisatawan. Rasa percaya dan ingin kembali adalah hasil dari kognisi warga dan wisatawan yang muncul. Karakteristik audiens atau publik yang relevan mengarah pada analisis audiens untuk mendefinisikan audiens target dalam hal penggunaan dan loyalitas.

f. $\quad$ Pre-requisites. Fasilitas pendukung wisata sungai kota kerap disediakan di area wisata Sungai Cikapundung seperti tempat pertunjukkan, kolam renang, tempat terapi melalui ikan dan sebagainya. Selain fasilitas yang lengkap, wisata Sungai Cikapundung pun sering menyediakan event. Infrastruktur public yang lengkap, event dan fasilitas pendukung lainnya menjadikan warga yang datang lebih terfasilitasi.

g. Purpose the channel. Wisata Sungai Cikapundung dan beragam fasilitas yang mendukungnya memerlukan pemilihan saluran komunikasi dan penyebaram informasi yang massif serta ekspose media, baik pribadi, sosial maupun massa. Memfungsikan semua saluran dan media ini membantu program pemerintah untuk mendapatkan tanggapan dari warga dan wisatawan. Penyebaran layanan media yang mudah diakses, seperti situs web www.bandungtourism.com dengan banyak pesan, surat elektronik dispar@bandungtourism.com, dan twitter@ Disbudpar.Bdg aktif dan interaktif, penuh warna dan menunjukkan kekompakan seluruh pemasaran.

h. Partnership. Kolaborasi dan kerjasama positif antara warga kota, pemerintah kota serta stakeholder lainnya, termasuk komunitas pecinta Cikapundung dan terutama pihak swasta seharusnya saling bahu-membahu mengomunikasikan wisata Sungai Cikapundung ini. Selain itu, tentu mempromosikan sebgaai bagian dari memanfaatkan untuk kelangsungan hidup warga kota melalui nilai ekonomi yang ada di sekitar wisata Sungai Cikapundung tersebut. Kerjasama dapat berupa penambahan prasarana maupun jaringan promosi itu sendiri.

$i$. Preservation the environment. Wisata sungai Cikapuntung tercipta salah satunya karena permasalahan lingkungan, yaitu kesadaran dan kepedulian masyarakat yang masih rendah terhadap sungai, hutan yang sering kali terjemah tangan tak bertanggung jawab serta permasalahan lingkungan lainnya. Wisata sungai kota memberi dampak yang besar tidak hanya pada ekonomi, sosial tetapi juga lingkungan. Peran berbagai pihak baik itu Balai Besar Wilayah Sungai (BBWS), dinas pemerintah kota, juga komunitas pegiat lingkungan yang sering melakukan aktivitas disekitar sungai membuat kesadaran masyarakat sekitar 


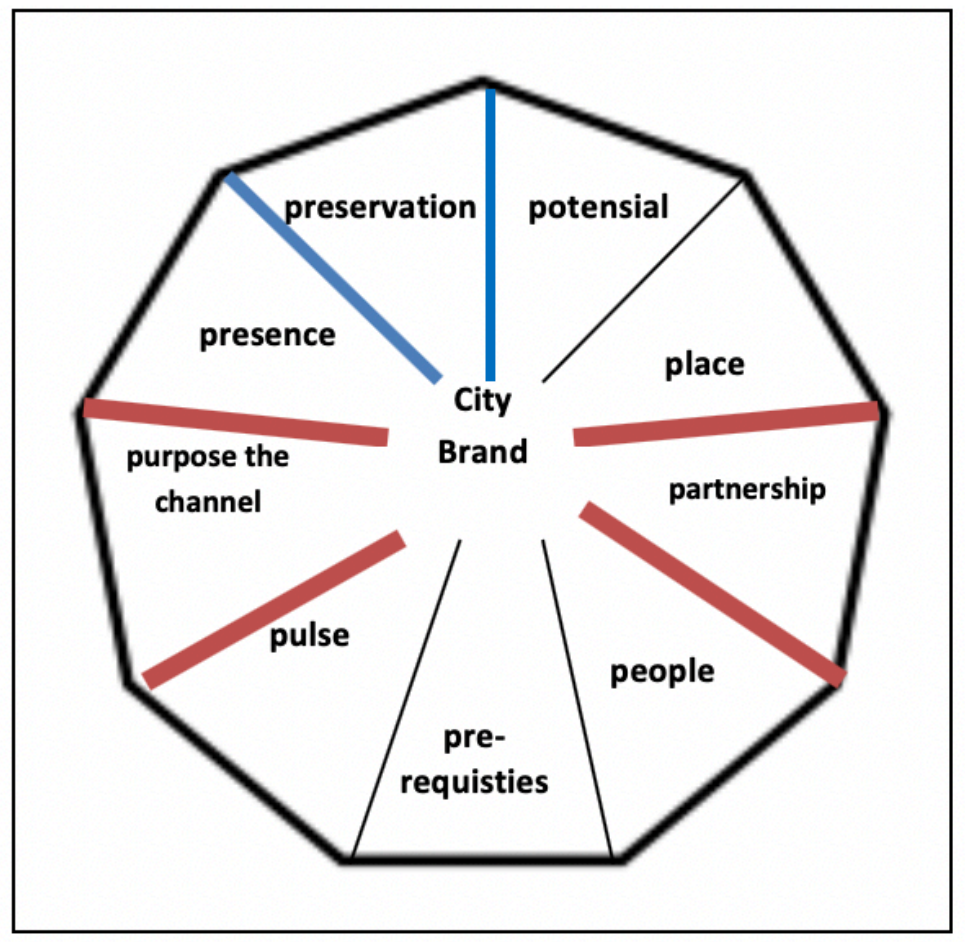

GAMBAR 1. Model City branding Nanogone

Sumber: Simon Anholt (2000) dan kontruksi peneliti (2019)

sungai pun mulai teredukasi dengan

keberadaan wisata sungai ini.

Berdasarkan pemaparan aspekaspek city branding, maka terbentuk kontruksi model city branding Nanogone yang dikontruksi berdasarkan Model Hexagone (Anholt, 2000), Model Octagone (Rozalena, 2019) mengenai city branding wisata buatan serta hasil penelitian yang dilakukan penulis.

\section{SIMPULAN}

Penelitian ini menghasilkan simpulan sebagai berikut.

1. Proses revitalisasi Sungai Cikapundung dalam membentuk branding Kota Bandung sebagai wisata buatan awalnya bertujuan untuk menyelamatkan aset negara, mengembalikan fungsi sungai yang sebenarnya serta mensukseskan salah satu tujuan Pemkot Bandung, yaitu meningkatkan indeks kebahagian warga kota. Seiring dengan revitalisasi yang terkonsep dan menjadi daya tarik, maka revitalisasi Sungai Cikapundung menjadi salah satu branding Kota Bandung

2. Strategi branding dalam mempromosikan wisata Sungai Kota Cikapundung sebagai objek wisata baru dilakukan dengan 1) penguatan padakonsep 3A (atraksi, aksesibilitas dan amenitas), 2) menciptakan tageline Stunning Bandung: where the wonders of West Java Begin menyatu dengan wisata kota lainnya, 3) mendukung program ruang ramah lingkungan dan menyenangkan dan promosi wisata kota. Strategi branding tersebut meningkatkan kunjungan wisatawan ke Kota Bandung

3. Model city brandingKota Bandung melalui revitalisasi Sungai Cikapundung berbentuk Nanogone yang meliputi aspek Presence, yaitu adanya persepsi kota Bandung yang memiliki ciri khas dari proses revitalisasi. Place, yaitu lokasi wisata buatan hasil 
revitalisasi sungai yang digemari. Potensial dalam arti memiliki potensi ekonomi dan pendidikan. Pulse, yaitu kaya akan ragam gaya hidup yang hegomoni. People, dimana masyarakat sebagai target hasil revitalisasi. Pre-requisites, yaitu fasilitas pendukung wisata yang lengkap. Purpose the channel, yaitu penyebaran informasi wisata kota yang menggunakan media yang beragam. Partnership, yaitu kolaborasi dan kerjasama positif antara warga kota, pemerintah kota serta stakeholder lainnyadan Preservation the environment, yaitu dampak dalam memberikan kesadaran pada lingkungan.

\section{DAFTAR PUSTAKA}

Damayanti, R. E. P., Nurhadi, K., \& Andini, I. (2015). Pengaruh Revitalisasi Sungai Terhadap Kinerja Sistem Drainase Kali Pepe Hilir Kota Surakarta. Region, 6(2), 51-60.

Dinnie, K. (2010). Introduction to the theory of city branding. In City branding: Theory and Cases (pp. 3-7). https:// doi.org/10.1057/9780230294790

Indriani, J., \& Kuswoyo, C. (2017). Pengaruh City branding Pada City Image Dan Keputusan Berkunjung Wisatawan Ke Kabupaten Purwakarta. Jurnal Manajemen Maranatha, 17(1), 41. https://doi.org/10.28932/jmm. v17i1.410

Kavaratzis, M. (2007). City Marketing: The Past, the Present and Some Unresolved. Geografy Compass, 1(3), 695-712. https://doi.org/https://doi.org/10.1111/ j.1749-8198.2007.00034.x

Kotler, P., \& Keller, K. L. (2008). Manajemen Pemasaran. Jakarta: PT Indeks.

Mathieson, A., \& Wall, G. (2005). Tourism : Economic, Phisical, and Social Impact. New York: John Wiley \& Son Inc.

Maylanny, C., \& Faridani, S. (2015). City branding Kota Bandung melalui Bus Bandros. Jurnal Komunikator, Vol.7 No.(1), 88-92.

Nugraha, A. (2019). Teks Wawancara. Bandung: Bagian Program Data Informasi Dinas Pariwisata dan Kebudayaan Kota Bandung.

Papp-Vary, A. (2011). C Ity -B Uilders $V s$. C Ity -D Efenders: 3(1), 555562. Retrieved from http://media. bizwebmedia.net/sites/146527/upload/ documents/branding_1.pdf

Purwianti, L., \& Ratna Dwi Lukito, Y. (2014). Analisis Pengaruh City branding Kota Batam Terhadap Brand Attitude (Studi Kasus Pada Stakeholder Di Kota Batam). Jurnal Manajemen, 14(1), 61-80.

Rozalena, A. (2017). Makna Simbolik Komunikasi Merek Kuliner Khas Palembang di Bandung. MediaTor, 10(2), 257-267. https://doi.org/https:// doi.org/10.29313/mediator.v10i2.3197

Rozalena, A. (2019). City branding Models Base On Artificial Tourism. Bandung: 1st International Conference on Social Science, Universitas Komputer. 1-11.

Wandari, L. A., Kumadji, S., \& Kusumawati, A. (2014). Pengaruh City branding " Shining Batu " Terhadap City Image Dan Keputusan Berkunjung Wisatawan Ke Kota Batu Tahun 2014. Jurnal Administrasi Bisnis, 16(1), 1-6.

Yuliana, A. Y. (2019). Teks Wawancara. Bandung: Satuan Kerja Operasi dan Pemeliharaan Sumber Daya Air Balai Besar Wilayah Sungai (BBWS) Citarum.

\section{UCAPAN TERIMA KASIH}

Penelitian ini didanai oleh Direktorat Riset dan Pengabdian Masyarakat Kementrian Riset, Teknologi dan Pendidikan Tinggi untuk Hibah Penelitian Dosen Pemula (PDP) tahun anggaran 2019. Sehubungan dengan itu, peneliti mengucapkan terima kasih yang sebesar-besarnya. 